\title{
Rozwój kompetencji społecznych studentów w dobie nauczania online
}

\author{
Development of students' social competence in an age \\ of online learning
}

\begin{abstract}
Streszczenie
Artykuł jest komunikatem z badań, których celem była próba odpowiedzi na pytanie, jak studenci oceniają rozwój swoich kompetencji społecznych w związku z nauką online, która stała się koniecznością z powodu pandemii COVID-19. W badaniu wzięło udział 350 studentów z trzech uczelni wyższych miasta Opola. Posłużono się metodą sondażu diagnostycznego. W celu zgromadzenia materiału badawczego wykorzystano kwestionariusz ankiety własnego autorstwa, w wersji online. Badani odpowiadali na pytania w oparciu o pięciostopniową skalę. Analiza wyników wskazuje na to, że respondenci najwyżej ocenili umiejętność zarządzania sobą w czasie $(M=3,71)$ oraz umiejętność wyrażania własnego zdania $(M=3,66)$, natomiast najniżej umiejętność podtrzymywania relacji $(\mathrm{M}=2,84)$ oraz systematyczność w uczeniu się (M=2,87). Okazało się także, że kobiety istotnie wyżej oceniły rozwój swoich kompetencji społecznych niż mężczyźni ( $M=3,44 ; M=2,94)$. Również istotnie wyższe oceny pojawiły się u studentów studiów zaocznych niż dziennych ( $M=3,63 ; M=3,27)$. Ponadto
\end{abstract}

1 Agnieszka Franczyk, Wydział Nauk Społecznych, Uniwersytet Opolski, Polska, e-mail: afranczyk@uni.opole.pl, ORCID ID: https://orcid.org/0000-0001-7240-3018.

2 Anna Rajchel, Wydział Ekonomii i Zarządzania, Politechnika Opolska, Polska, e-mail: a.rajchel@po.edu.pl, ORCID ID: https://orcid.org/0000-0002-9354-1927. 
studenci pierwszych lat istotnie wyżej ocenili innowacyjne podejście do rozwiązywania problemów i systematyczność w uczeniu się niż studenci starsi stażem.

\title{
Słowa kluczowe:
}

kompetencje społeczne, nauczanie online, studenci, COVID-19, rozwój kompetencji

\begin{abstract}
The article is the research report. The aim of the investigation was to address the question how students evaluate the development of their social competence regarding learning online which became inevitable due to the COVID-19 pandemic. 350 students from three universities in Opole participated in the research. The diagnostic survey method was applied. In order to collect the research material, an original online survey questionnaire was used. The study participants responded to questions on the basis of a five-point scale. The analysis of the results indicates that the highest valued competence for the respondents was the ability of self-management in time (M=3.71) along with the ability of expressing one's own opinion $(\mathrm{M}=3.66)$, whereas the lowest valued competence was maintaining relations $(\mathrm{M}=2.84)$ and regularity of learning $(\mathrm{M}=2.87)$. It also turned out that women valued the development of their social competence significantly higher than men ( $M=3.44 ; M=2.94)$. Considerably higher results also appeared in extramural students compared to full-time students ( $M=3.63 ; M=3.27)$. Moreover, early years students rated the innovative approach to problemsolving and systematic learning significantly higher than older students.
\end{abstract}

\section{Keywords:}

social competence, online learning, students, COVID-19, development of competences.

Dynamiczny rozwój nauki i techniki, zmiany gospodarcze, polityczne i społeczne zachodzące w świecie, pojawienie się nowego pokolenia na rynku pracy wychowanego w erze internetu, dla którego nowe technologie nie powinny stanowić problemu, spowodowały nowe spojrzenie na problematykę kompetencji. Wirus SARS-CoV-2, który pojawił się we wszystkich krajach, wprowadzanie przez poszczególne rządy lockdownu, zamknięcie szkół, sklepów, urzędów oraz innych instytucji, przejście od pracy stacjonarnej do online obnażyło bardzo wiele braków zarówno wśród dzieci, młodzieży i dorosłych, związanych z szeroko rozumianymi kompetencjami cyfrowymi. Szkolenia, kursy organizowane przez pracodawców 
i skierowane do pracowników, uczniów, studentów miały przede wszystkim pomóc przejść od świata offline do online. Od marca 2020 roku polska młodzież nie może uczyć się stacjonarnie. Uczniowie i studenci kontaktują się z prowadzącymi zajęcia za pośrednictwem sprzętu komputerowego. Realizowany jest materiał, studenci podchodzą do zaliczeń, egzaminów i obron, korzystając ze specjalistycznego oprogramowania. Młodzież musiała nauczyć się pracować w domu, bez kontaktu z rówieśnikami. Ograniczenia związane z przemieszczaniem się, ograniczenie spotkań do niezbędnego i koniecznego minimum wpłynęło również na poziom kompetencji społecznych młodych ludzi. Szkoły i uczelnie stanęły przed nowym wyzwaniem.

Celem artykułu jest próba odpowiedzi na pytanie, jak studenci postrzegają rozwój kompetencji społecznych w dobie nauczania online. W części pierwszej zaprezentowano wybrane definicje dotyczące kompetencji oraz kompetencji społecznych. Część druga to analiza badań przeprowadzonych wśród studentów opolskich uczelni: Uniwersytetu Opolskiego, Politechniki Opolskiej, Wyższej Szkoły Bankowej Wydział Ekonomiczny w Opolu.

\section{WIELOZNACZNOŚĆ TERMINU KOMPETENCJE}

Termin kompetencje jest wieloznaczny i interdyscyplinarny. Występuje m.in. w naukach o zarządzaniu i organizacji, zarządzaniu kapitałem ludzkim, psychologii, pedagogice, socjologii, prawie i innych dyscyplinach naukowych. W języku potocznym kompetencje utożsamiane są z umiejętnościami czy kwalifikacjami, co nie zawsze jest prawidłowe.

Kompetencje (...) to pojęcie szersze od kwalifikacji, obejmujące swoim zakresem ogół trwałych właściwości człowieka tworzących związek przyczynowo-skutkowy z osiąganymi przez niego wysokimi i/lub ponadprzeciętnymi efektami pracy, które mają swój mierzalny wymiar (Pocztowski, 2008, s. 117).

Umiejętności natomiast to „sprawność w posługiwaniu się odpowiednimi wiadomościami przy wykonywaniu określonych zadań” (Okoń, 1981, s. 329).

Termin kompetencje „pochodzi z łaciny competentia i oznacza praktyczną umiejętność, przydatność, zdolność do wykonywania czegoś, jakiejś czynności” (Kompetencje społeczne, s. 2).

Według Słownika języka polskiego pod red. M. Szymczaka kompetencje to: 
1. „zakres uprawnień, pełnomocnictw, zakres działania jakiejś instytucji lub spraw podlegających określonemu organowi itp.;

2. zakres czyjejś wiedzy, umiejętności lub odpowiedzialności” (Szymczak, 1982, s. 977).

W naukach o zarządzaniu i organizacji kompetencje utożsamiane są ze zdolnością, uprawnieniem do określonego działania. Rys. 1 przedstawia znaczenie terminu kompetencje w ujęciu S. Whiddetta i S. Hollyforde’a.

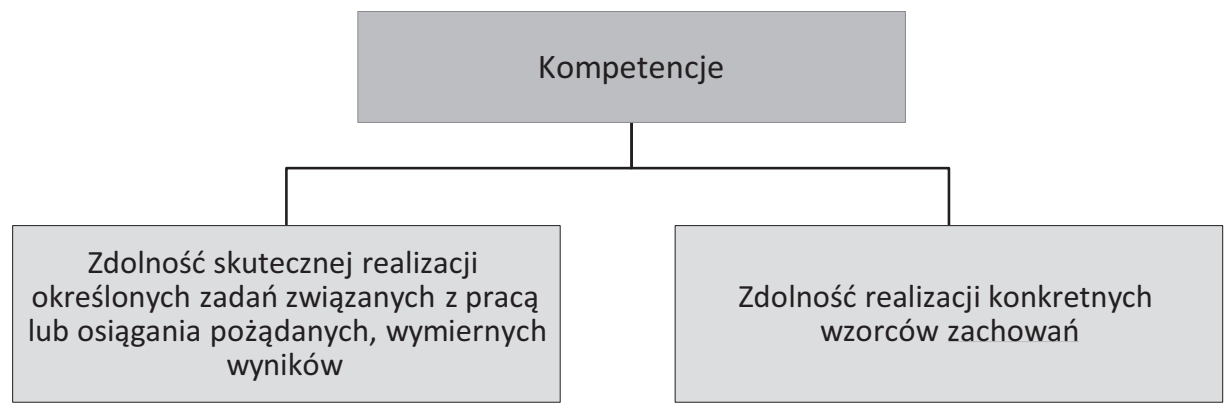

Rys. 1. Pojęcie kompetencji wg S. Whiddetta i S. Hollyforde’a

Źródło: opracowanie własne na podstawie: S. Whiddett, S., Hollyforde, Modele kompetencyjne w zarzq̨dzaniu zasobami ludzkimi, przeł. G. Sałuda, Oficyna Ekonomiczna, Kraków 2003, s. 15.

W definicji tej autorzy szczególną uwagę zwrócili na aspekt zdolności. Kompetencje to określona zdolność, która może być utożsamiana z umiejętnością. Nastąpiło połączenie dwóch terminów.

\section{Zdolność + Umiejętność = Kompetencje}

Ta interpretacja bliska jest tej zawartej w Słowniku języka polskiego pod red. W. Doroszewskiego w którym kompetencje oznaczają:

1. „zakres uprawnień urzędu lub urzędnika do zajmowania się określonymi sprawami i podejmowania dotyczących ich decyzji;

2. zakres czyjejś wiedzy, umiejętności i doświadczenia; zdolność komórek do reagowania na określone bodźce” (Doroszewski).

\section{Uprawnienia + Wiedza + Umiejętności + Doświadczenie $=$ Kompetencje}


Wybrane definicje kompetencji występujące w zarządzaniu zasobami ludzkimi przedstawia tabela 1.

Tabela 1. Wybrane definicje kompetencji

\begin{tabular}{|c|c|}
\hline Autor & Definicja \\
\hline A. Rogozińska-Pawełczyk & $\begin{array}{l}\text { Zakres wiedzy, umiejętności i odpowiedzialności, zakres pełno- } \\
\text { mocnictw i uprawnień do działania. Kompetentny - to uprawniony } \\
\text { do działania i decydowania, mający podstawy i kwalifikacje do } \\
\text { wydawania opinii i sądów (...) są charakterystyczne dla dokładnie } \\
\text { określonych sytuacji oraz specyficznych kontekstów organiza- } \\
\text { cyjnych, to znaczy, że ujawniają się one podczas wykonywania } \\
\text { konkretnej działalności zawodowej (...) (cyt. za: Rogozińska- } \\
\text {-Pawełczyk, 2006, s. 101). }\end{array}$ \\
\hline J. Dudzińska-Głaz & $\begin{array}{l}\text { Pojęcie kompetencji jest związane z właściwościami osobowymi } \\
\text { pojedynczych pracowników, które są niezbędne dla odpowiednie- } \\
\text { go wykonania pracy na danym stanowisku i właściwego funkcjo- } \\
\text { nowania organizacji (Dudzińska-Głaz, 2012, s. 84). }\end{array}$ \\
\hline R. E. Boyatzis & $\begin{array}{l}\text { Potencjał istniejący w człowieku, prowadzący do takiego zacho- } \\
\text { wania, które przyczynia się do zaspokojenia wymagań na danym } \\
\text { stanowisku pracy w ramach parametrów otoczenia organizacji, } \\
\text { co z kolei daje pożądane wyniki (cyt. za: Armstrong, 2000, } \\
\text { s. 241-242). }\end{array}$ \\
\hline
\end{tabular}

Źródło: Opracowanie własne.

Na podstawie przytoczonych definicji można zauważyć, że:

1. Kompetencje to wiedza, umiejętność i odpowiedzialność.

2. Kompetencje to właściwość osobowa ludzi/pracowników.

3. Kompetencje to potencjał istniejący w człowieku.

W psychologii i pedagogice termin ten pojawił się w latach 80. XX w. „Uznano wówczas, że kompetencje są wynikiem uczenia się, a osoba kompetentna to taka, która jest dobrze przygotowana do wykonywania zawodu i gotowa do sprawnego działania” (cyt. za: Kocór, 2011, bs.).

Na podstawie przytoczonych definicji można wyróżnić kilka komponentów kompetencji, które przedstawia rys. 2.

\section{RODZAJE KOMPETENCJI}

W literaturze poświęconej problematyce kompetencji można wyróżnić wiele rodzajów kompetencji w zależności od dyscypliny naukowej. Tabela 2 przedstawia wybrane rodzaje kompetencji. 


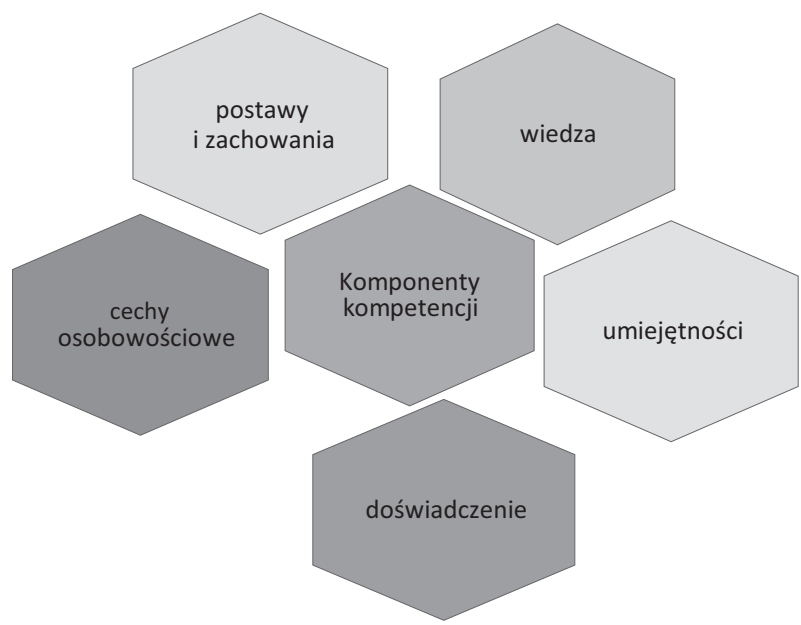

Rys. 2. Komponenty kompetencji

Źródło: opracowanie własne na podstawie: W. Załoga, Model kompetencji menedżera w nowoczesnej organizacji, „Zeszyty Naukowe Uniwersytetu Przyrodniczo-Humanistycznego w Siedlcach nr 97, Seria: Administracja i Zarządzanie 2013, s. 457-458. Pobrane z: https://repozytorium.uph.edu.pl/bitstream/handle/11331/730/ Zaloga_Model_kompetencji_menedzera.pdf?sequence=1.

Tabela 2. Wybrane rodzaje kompetencji

\begin{tabular}{|c|c|}
\hline $\begin{array}{c}\text { Rodzaj kompe- } \\
\text { tencji }\end{array}$ & Definicja \\
\hline $\begin{array}{l}\text { kompetencja komu- } \\
\text { nikacyjna }\end{array}$ & $\begin{array}{l}\text { Kompetencja dotycząca użycia języka, która jest czymś innym niż fak- } \\
\text { tycznym użyciem języka w procesie komunikacji. (...) Teoria uwzględ- } \\
\text { nia znajomość kompetencji gramatycznej, ale też akceptowalnych } \\
\text { w danej kulturze sposobów interakcji z innymi w różnych sytuacjach } \\
\text { i będących w różnych wzajemnych relacjach. Termin wprowadzony } \\
\text { przez D. Hymesa (cyt. za: Siek-Piskozub, 2012, s. 96). }\end{array}$ \\
\hline $\begin{array}{l}\text { kompetencje beha- } \\
\text { wioralne }\end{array}$ & $\begin{array}{l}\text { Skupiają się na sposobie zachowania się; to inaczej potencjał danej } \\
\text { osoby, jej zasoby i możliwości generowania zachowań uważanych za } \\
\text { niezbędne i adekwatne np. w pełnieniu określonej roli zawodowej. } \\
\text { Ocenienie kompetencji danej osoby wymaga obserwacji jej działań } \\
\text { w różnym kontekście sytuacyjnym (Fastnacht, 2006, s. 110). }\end{array}$ \\
\hline $\begin{array}{l}\text { kompetencje po- } \\
\text { znawcze }\end{array}$ & $\begin{array}{l}\text { Potocznie nazywane kompetencjami myślenia. Jest to pojęcie bardzo } \\
\text { szerokie, obejmujące zarówno kreatywność, jak i logiczne rozumowanie } \\
\text { i rozwiązywanie złożonych problemów (Włoch, Śledziewska, s. 11). }\end{array}$ \\
\hline $\begin{array}{l}\text { kompetencje kultu- } \\
\text { rowe }\end{array}$ & $\begin{array}{l}\text { Zbiór zbieżnych zachowań, postaw i polityk, które łączą się w system, } \\
\text { grupy specjalistów i umożliwiają systemowi oraz specjalistom efektyw- } \\
\text { ne działanie w sytuacjach międzykulturowych (cyt. za: Kompetencje } \\
\text { kulturowe..., s. 17). }\end{array}$ \\
\hline $\begin{array}{l}\text { kompetencje } \\
\text { wychowawcze } \\
\text { i diagnostyczne }\end{array}$ & $\begin{array}{l}\text { Odnoszą się do wiedzy i umiejętności, które umożliwiają prowadzenie } \\
\text { procesu wychowania w środowisku szkolnym (Pankowska, 2016, } \\
\text { s. 189). }\end{array}$ \\
\hline
\end{tabular}

Źródło: opracowanie własne. 
Według Wielkiego Słownika Języka Polskiego kompetencje dzielą się m.in. na:

1. „zawodowe - zdolność do wykonywania pewnych czynności, oparta na wiedzy i doświadczeniu oraz

2. ustawowe - prawo do wydawania decyzji przysługujące osobie, która pełni jakąś oficjalną funkcję” (Wielki Słownik Języka Polskiego, bs.).

\section{KOMPETENCJE SPOŁECZNE}

Kompetencje społeczne są jednymi z najważniejszych, ponieważ to przede wszystkim one pozwalają funkcjonować człowiekowi w społeczeństwie, dostosowywać się do zmian zachodzących w grupach. Dzięki nim tworzą się kontakty interpersonalne, ludzie komunikują się, wchodzą w związki i relacje z innymi osobami.

Według K. Henne w skład tej kompetencji rozumianej jako „zdolności ogólne wchodzą:

- umiejętność adaptacyjna (zdolność przystosowania się i plastyczności zachowań w różnych kontekstach sytuacyjnych);

- umiejętność budowania więzi emocjonalnej (zdolność do tworzenia satysfakcjonujących relacji emocjonalnych i otrzymywania społecznego wsparcia);

- umiejętność efektywnego komunikowania się (zdolność do właściwego odczytywania intencji i interpretacji cudzych komunikatów, oraz odpowiedniego na nie reagowania);

- zdolność osiągania własnych celów (sprawczość w działaniu i kontaktach interpersonalnych” (Henne, 2003, s. 113).

Inną definicję zaprezentował M. Argyle w Psychologii stosunków międzyludzkich. Kompetencja społeczna to „zdolność, posiadanie, niezbędnych umiejętności do tego, by wywrzeć pożądany wpływ na innych ludzi w sytuacjach społecznych (...). Kompetencja społeczna ma wiele składników, np. empatia, podejmowanie ról innych ludzi, inteligencja społeczna i rozwiązywanie problemów, komunikacja niewerbalna, komunikacja werbalna” (Argyle, 2001, s. 133 i nast.).

W świetle Zalecenia Rady z dnia 22 maja 2018 r. w sprawie kompetencji kluczowych w procesie uczenia się przez całe życie jest to jedna z ośmiu kompetencji kluczowych. Kompetencje te przedstawia rys. 3.

W świetle zalecenia kompetencje osobiste, społeczne i w zakresie umiejętności uczenia się to: „zdolność do autorefleksji, skuteczne zarządzanie czasem i informacjami, konstruktywna praca z innymi osobami, zachowanie odporności oraz zarządzanie własnym uczeniem się i karierą zawodową. Obejmują one zdolność 


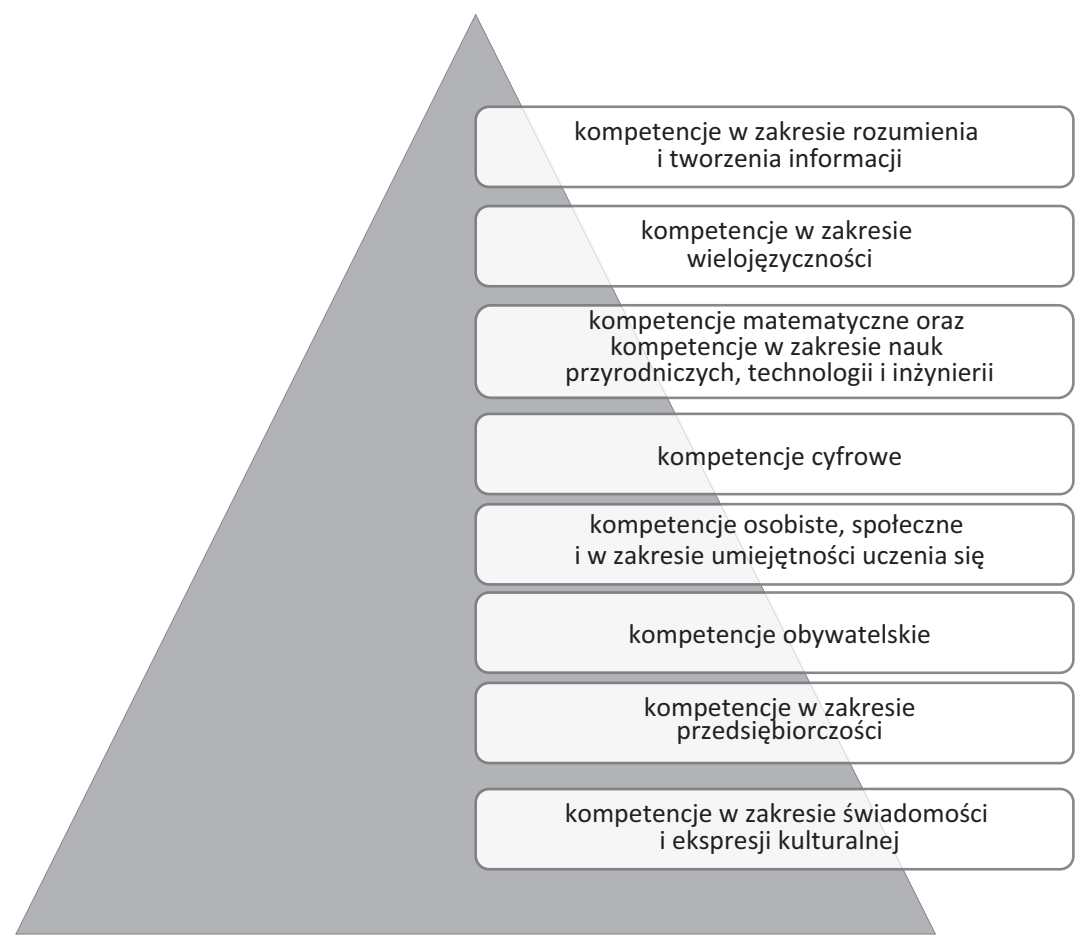

Rys. 3. Kompetencje kluczowe

Źródło: opracowanie własne na podstawie: Zalecenie Rady z dnia 22 maja 2018 r. w sprawie kompetencji kluczowych w procesie uczenia się przez całe życie (Tekst mający znaczenie dla EOG) (2018/C 189/01), Dziennik Urzędowy Unii Europejskiej, https://eur-lex.europa. eu/legal-content/PL/TXT/PDF/?uri=CELEX:32018H0604(01)\&from=en.

radzenia sobie z niepewnością i złożonością, umiejętność uczenia się, wspierania swojego dobrostanu fizycznego i emocjonalnego, utrzymania zdrowia fizycznego i psychicznego oraz zdolność do prowadzenia prozdrowotnego i zorientowanego na przyszłość trybu życia, odczuwania empatii i zarządzania konfliktami we włączającym i wspierającym kontekście” (Zalecenia, s. 10).

Według Polskiej Ramy Kwalifikacji dla szkolnictwa wyższego wyróżniono trzy poziomy: wiedzę, umiejętności i kompetencje społeczne. Przedstawia je rys. 4.

W świetle ustawy z dnia 22 grudnia 2015 r. o Zintegrowanym Systemie Kwalifikacji (Dz. U. 2016 poz. 64 z późn. zm.) kompetencje społeczne to „rozwinięta w toku uczenia się zdolność kształtowania własnego rozwoju oraz autonomicznego i odpowiedzialnego uczestniczenia w życiu zawodowym i społecznym, z uwzględnieniem etycznego kontekstu własnego postępowania” (Ustawa z dnia 22 grudnia 2015 r. ...). 


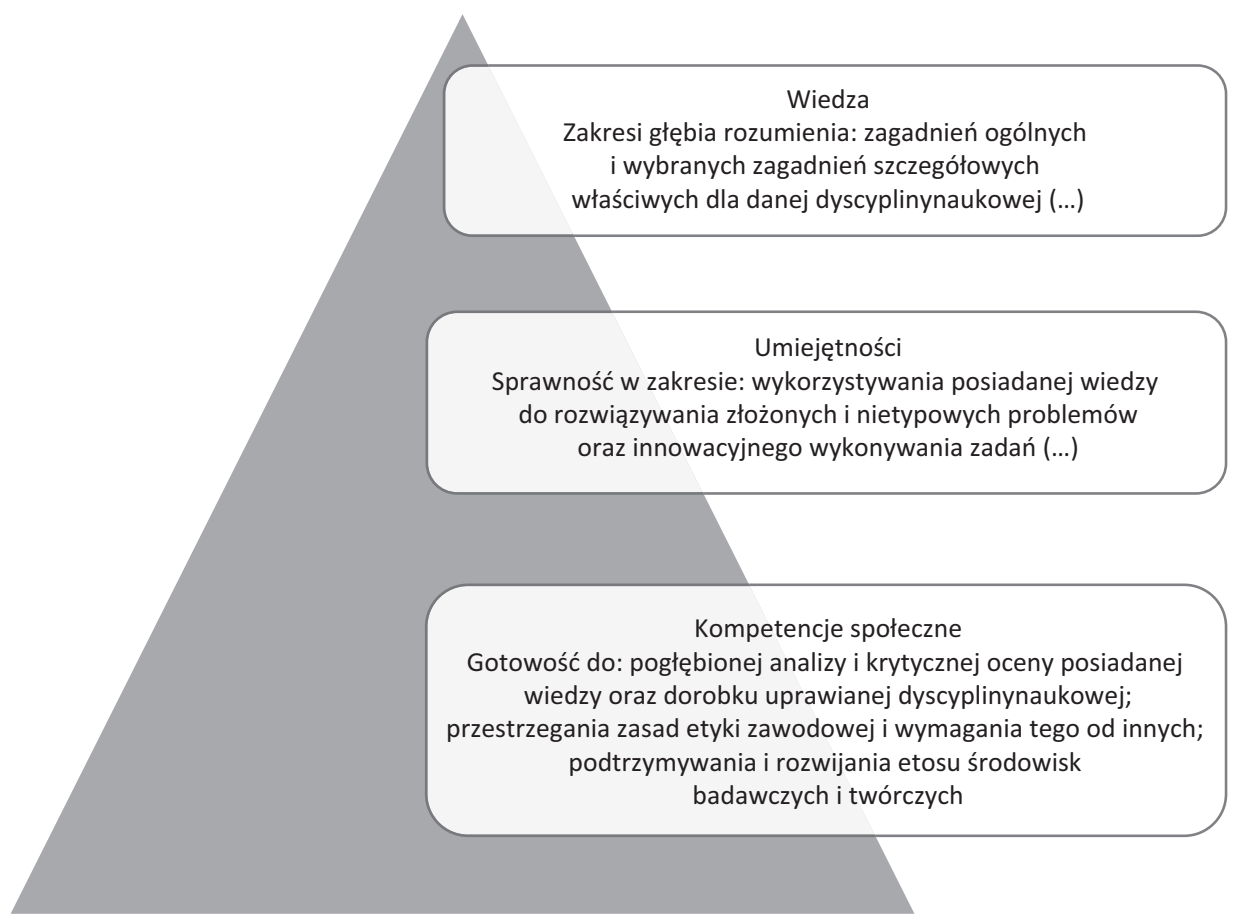

Rys. 4. Poziomy kompetencji

Źródło: opracowanie własne na podstawie: Polska Rama Kwalifikacji. Poradnik użytkownika, Warszawa 2018, https://kwalifikacje.edu.pl/wp-content/uploads/publikacje/PDF/PRK_PU-2018_B_www.pdf, s. 10.

Kompetencje społeczne mogą mieć charakter:

1. ,adaptacyjny - pozwalają na efektywność i skuteczność działań, odnajdywanie się na rynku pracy, bycie przedsiębiorczym i komunikatywnym,

2. emancypacyjny - pozwalają na rozumienie rzeczywistości społecznej, dokonywanie wyborów i działanie ze świadomością konsekwencji związanych z tymi wyborami (np. świadomość ról społecznych, gotowość do działania na rzecz interesu publicznego),

3. krytyczny - pozwalają na dostrzeganie uzasadnień legitymizujących własne działanie oraz praktykę społeczną, umożliwiające rozumienie własnej sytuacji oraz kontekstów, w jakich przebiega działanie kreatywne, niezależne oraz etyczne” (cyt. za: Miłaszewicz, 2017, s. 151). 


\section{PROBLEMY BADAWCZE}

Główny problem badawczy zawarto w pytaniu: Jak studenci oceniają rozwój swoich kompetencji społecznych w związku z nauką online? Dodatkowo sformułowano następujące problemy szczegółowe:

a. Czy ocena studentów dotycząca rozwoju ich kompetencji społecznych podczas nauki online jest różnicowana przez płeć?

b. Czy ocena studentów dotycząca rozwoju ich kompetencji społecznych podczas nauki online jest różnicowana przez tryb studiów?

c. Czy ocena studentów dotycząca rozwoju ich kompetencji społecznych jest różnicowana przez okres studiowania online?

Zmienną zależną w badaniu stanowi rozwój kompetencji społecznych, a jego wskaźnikiem jest ocena studentów wyrażona na pięciostanowej skali, dokonana w odniesieniu do dziewięciu wybranych kompetencji. W badaniu uwzględniono trzy zmienne niezależne: płeć (kobieta vs mężczyzna), tryb studiów (dzienne vs zaoczne) oraz czas studiowania online (krótko vs długo). Przyjęto, że osoby, które mają za sobą jeden semestr studiów online - studiują krótko, natomiast te, które mają za sobą co najmniej dwa semestry - długo. Z uwagi na eksploracyjny charakter badań zrezygnowano z formułowania hipotez badawczych.

\section{METODA}

\subsection{OSOBY BADANE}

W badaniu wzięło udział 350 studentów z trzech opolskich uczelni: Uniwersytetu Opolskiego (56,6\%), Politechniki Opolskiej (32\%) oraz Wyższej Szkoły Bankowej, Wydziału Ekonomicznego w Opolu (11,4\%). W grupie badawczej uwzględniono osoby studiujące takie kierunki, jak: pedagogika (56\%), informatyka (12\%), ekonomia (8,6\%), filologia $(5,1 \%)$, praca socjalna (2,9\%), biologia (2\%), informatyka (1,9\%), historia (1,7\%), administracja (1,7\%), matematyka $(1,1 \%)$ i inne (2,9\%). Wśród osób badanych większość stanowiły kobiety (78,9\%), natomiast mężczyźni - 21,1\%. Przeważająca część respondentów studiowała w trybie dziennym (82\%), pozostali w trybie zaocznym (18\%). Większość stanowiły osoby studiujące na I roku studiów, będące po pierwszym semestrze nauki online (71,7\%), a 28,3\% stanowili studenci późniejszych lat. Dobór próby miał charakter nieprobabilistyczny. 


\subsection{PROCEDURA BADAŃ}

Badania zrealizowano w okresie od 27.02.2021 do 13.03.2021. Posłużono się metodą sondażu diagnostycznego. W celu zgromadzenia materiału badawczego wykorzystano kwestionariusz ankiety własnego autorstwa, w wersji online. Kwestionariusz zawierał pytania dotyczące rozwoju dziewięciu wybranych kompetencji społecznych. Respondenci udzielali odpowiedzi w oparciu o pięciostopniową skalę, gdzie 1 oznaczało Zdecydowanie nie, 2 - Raczej nie, 3 - Trudno powiedzieć, 4 Raczej tak, 5 - Zdecydowanie tak. W narzędziu badawczym postawiono także jedno pytanie otwarte, które brzmiało: Jaka jest Twoja opinia na temat edukacji online? W metryczce zawarto pytania o tryb studiów, kierunek, rok studiów, poziom studiów (pierwszy stopień, drugi stopień, jednolite magisterskie), rodzaj uczelni, płeć oraz miejsce zamieszkania.

Uzyskane dane empiryczne poddano analizie statystycznej w programie Statistica 13.3 (StatSoft Polska). Sprawdzenie normalności rozkładu zmiennych zrealizowano za pomocą testu Shapiro-Wilka. Ponieważ rozkład zmiennych odbiegał od rozkładu normalnego i nie zostało spełnione założenie o homogeniczności wariancji, w analizie wykorzystano nieparametryczny test $U$ Manna-Whitneya oraz test korelacji rang Spearmana. W celu wskazania na istnienie istotnych statystycznie różnic między grupami przyjęto poziom istotności p<0,05.

\subsection{WYNIKI}

W toku analiz postanowiono sprawdzić, czy między poszczególnymi kompetencjami istnieją korelacje. W tym celu zastosowano test korelacji rang Spearmana (tabela 3).

Analiza wyników zawartych w tabeli 3 pozwala stwierdzić, że między wszystkimi kompetencjami społecznymi wystąpiły istotne dodatnie korelacje, co oznacza, że kwestionariusz ankiety rzeczywiście badał kompetencje społeczne. Wysoką dodatnią korelację odnotowano pomiędzy zarządzaniem sobą w czasie a organizacją i planowaniem własnej pracy. Średnie dodatnie korelacje wystąpiły m.in. pomiędzy zarządzaniem sobą w czasie a systematycznością w uczeniu się, organizacją i planowaniem własnej pracy a systematycznością w uczeniu się, podtrzymywaniem relacji a umiejętnością pracy w grupie czy podtrzymywaniem relacji a empatią, a także pomiędzy kreatywnością a innowacyjnym podejściem do rozwiązywania problemów. 
Tabela 3. Korelacje pomiędzy poszczególnymi kompetencjami społecznymi

\begin{tabular}{|c|c|c|c|c|c|c|c|c|c|}
\hline $\begin{array}{l}\text { Kompetencje } \\
\text { społeczne }\end{array}$ & WYR & POD & EMP & KRE & INN & PRG & ORG & ZARZ & SYS \\
\hline WYR & & $0,45^{*}$ & $0,47^{*}$ & $0,43^{*}$ & $0,35 *$ & $0,37 *$ & $0,34 *$ & $0,33 *$ & $0,30^{*}$ \\
\hline POD & & & $0,55^{*}$ & $0,44^{*}$ & $0,36 *$ & $0,55^{*}$ & $0,30 *$ & $0,29 *$ & $0,39 *$ \\
\hline EMP & & & & $0,49 *$ & $0,44^{*}$ & $0,47^{*}$ & $0,41 *$ & $0,35 *$ & $0,37 *$ \\
\hline KRE & & & & & $0,64^{*}$ & $0,50 *$ & $0,48^{*}$ & $0,44^{*}$ & $0,48^{*}$ \\
\hline INN & & & & & & $0,46 *$ & $0,48 *$ & $0,43^{*}$ & $0,44^{*}$ \\
\hline PRG & & & & & & & $0,37 *$ & $0,33 *$ & $0,40^{*}$ \\
\hline ORG & & & & & & & & $0,77^{*}$ & $0,62^{*}$ \\
\hline ZARZ & & & & & & & & & $0,61^{*}$ \\
\hline SYS & & & & & & & & & \\
\hline
\end{tabular}

$* \mathrm{p}<0,05$

Legenda: WYR - Wyrażanie własnego zdania, POD - Podtrzymywanie relacji, EMP - Empatia, KRE - Kreatywność, INN - Innowacyjne podejście do rozwiązywania problemów, PRA - Praca w grupie, ORG - Organizacja i planowanie pracy własnej, ZARZ - Zarządzanie sobą w czasie, SYS - Systematyczność w uczeniu się.

Źródło: badania własne.

W badaniu poszukiwano odpowiedzi na pytanie, jak studenci oceniają rozwój swoich kompetencji społecznych w związku z nauką online. Poniżej zaprezentowano średnie i odchylenia standardowe dla każdej kompetencji z uwzględnieniem podziału na płeć.

Tabela 4. Średnie i odchylenia standardowe dla oceny rozwoju kompetencji społecznych z uwzględnieniem płci studentów

\begin{tabular}{lcccccc}
\hline \multirow{2}{*}{ Kompetencje społeczne } & \multicolumn{2}{c}{$\begin{array}{c}\text { Kobiety } \\
\text { (N=276) }\end{array}$} & \multicolumn{2}{c}{$\begin{array}{c}\text { Mężczyźni } \\
\text { (N=74) }\end{array}$} & \multicolumn{2}{c}{$\begin{array}{c}\text { Ogółem } \\
\text { (N=350) }\end{array}$} \\
\cline { 2 - 7 } & Średnia & $\begin{array}{c}\text { Odch. } \\
\text { Stand. }\end{array}$ & Średnia & $\begin{array}{c}\text { Odch. } \\
\text { stand. }\end{array}$ & Średnia & $\begin{array}{c}\text { Odch. } \\
\text { stand. }\end{array}$ \\
\hline Wrażanie własnego zdania & 3,75 & 0,99 & 3,31 & 0,98 & 3,66 & 1 \\
\hline Podtrzymywanie relacji & 2,93 & 1,21 & 2,50 & 1,25 & 2,84 & 1,23 \\
\hline Empatia & 3,51 & 1,05 & 2,97 & 1,09 & 3,4 & 1,08 \\
\hline Kreatywność & 3,31 & 1,19 & 2,78 & 1,14 & 3,2 & 1,19 \\
\hline $\begin{array}{l}\text { Innowacyjne podejście do } \\
\text { rozwiązywania problemów }\end{array}$ & 3,57 & 1,06 & 3,32 & 1,02 & 3,52 & 1,06 \\
\hline Praca w grupie & 3,27 & 1,28 & 2,93 & 1,23 & 3,2 & 1,27 \\
\hline $\begin{array}{l}\text { Organizacja i planowanie } \\
\text { pracy własnej }\end{array}$ & 3,75 & 1,23 & 3,08 & 1,30 & 3,61 & 1,27 \\
\hline
\end{tabular}




\begin{tabular}{lcccccc}
\hline \multirow{2}{*}{ Kompetencje społeczne } & \multicolumn{2}{c}{$\begin{array}{c}\text { Kobiety } \\
(\mathbf{N = 2 7 6 )}\end{array}$} & \multicolumn{2}{c}{$\begin{array}{c}\text { Mężczyźni } \\
(\mathbf{N = 7 4 )}\end{array}$} & \multicolumn{2}{c}{$\begin{array}{c}\text { Ogółem } \\
(\mathbf{N = 3 5 0 )}\end{array}$} \\
\cline { 2 - 7 } & Średnia & $\begin{array}{l}\text { Odch. } \\
\text { Stand. }\end{array}$ & Średnia & $\begin{array}{l}\text { Odch. } \\
\text { stand. }\end{array}$ & Średnia & $\begin{array}{c}\text { Odch. } \\
\text { stand. }\end{array}$ \\
\hline Zarządzanie sobą w czasie & 3,87 & 1,18 & 3,11 & 1,28 & 3,71 & 1,24 \\
\hline $\begin{array}{l}\text { Systematyczność w uczeniu } \\
\text { się }\end{array}$ & 3,00 & 1,33 & 2,41 & 1,13 & 2,87 & 1,32 \\
\hline
\end{tabular}

Źródło: badania własne.

Analiza wyników wskazuje na to, że respondenci najwyżej ocenili umiejętność zarządzania sobą w czasie $(\mathrm{M}=3,71)$, umiejętność wyrażania własnego zdania $(M=3,66)$ oraz organizacji i planowania pracy własnej $(M=4,61)$, natomiast najniżej - podtrzymywanie relacji $(M=2,84)$ oraz systematyczność w uczeniu się $(\mathrm{M}=2,87)$. Pozwala to założyć, że edukacja online nie sprzyja rozwijaniu relacji interpersonalnych w takim stopniu, jak było to możliwe podczas zajęć stacjonarnych, oraz utrudnia systematyczne uczenie się, co też wybrzmiało w odpowiedziach pozostawionych na zawarte w kwestionariuszu pytanie otwarte: Jaka jest Twoja opinia na temat edukacji online? Poniżej przywołano kilka egzemplifikacji:

Myślę, że to dobra alternatywa dla osób zamieszkujących daleko od miejsca studiowania i mających problem z dojazdami. Jednak jeśli chodzi o budowanie więzi, czy umacnianie w sobie samodyscypliny czy też kontaktów międzyludzkich, jest to jednak krzywdzące.

Moim zdaniem, edukacja online upośledza kontakty między ludźmi. Nauka jest mniej efektywna, ponieważ posiadamy wokół siebie więcej bodźców, które odwracają naszą uwagę od zajęć.

Sądzę, że studentom brakuje motywacji, a przede wszystkim dyscypliny. Zajęcia stacjonarne wymagają większego skupienia, w domu natomiast można się łatwiej rozproszyć, co może wpływać negatywnie na efektywność nauki.

(...) mam problem z tworzeniem notatek oraz systematycznym przygotowaniem się do zajęć.

Wśród głosów wskazujących na trudność w podtrzymywaniu relacji $(M=2,84)$ w związku z edukacją online pojawiły się jeszcze takie jak: 
Uważam, że zdalna edukacja wpływa niekorzystnie na rozwój psychospołeczny (...) brakuje radości ze studiowania, entuzjazmu, dzielenia się własnymi przeżyciami i emocjami z koleżankami i kolegami z roku (...).

Ciężko utrzymać relacje z rówieśnikami (...).

Moim zdaniem edukacja online nie oddaje w pełni zajęć stacjonarnych, ponieważ brakuje kontaktu interpersonalnego z wykładowcami oraz koleżankami i kolegami.

Brakuje mi bezpośredniego kontaktu z prowadzącymi i uczestnikami spotkań.

Co ciekawe, mimo iż kształtowanie systematyczności w uczeniu się w trakcie nauki online zostało tak nisko ocenione ( $M=2,87)$, to jedną z najwyżej ocenionych kompetencji okazało się zarządzanie sobą w czasie $(\mathrm{M}=3,71)$. Pozornie mogłoby się wydawać, że systematyczność ściśle wiąże się z planowaniem swojego czasu, jednak prawdopodobnie badani studenci rozpatrzyli tę umiejętność w szerszym kontekście, nie tylko w odniesieniu do wygospodarowywania czasu na naukę. Stwierdzono za to wysoką dodatnią korelacją między zarządzaniem sobą w czasie $(\mathrm{M}=3,71)$ a umiejętnością organizowania i planowania własnej pracy, której rozwój został oceniony również wysoko $(\mathrm{M}=3,60)$. Na możliwość ich kształtowania w trakcie edukacji online wskazali studenci w następujących wypowiedziach:

(...) mniej angażuję się w zajęcia zdalne, ale nauczyłam się np. zarządzać czasem.

Moim zdaniem edukacja online poszerza nasze horyzonty, pobudza kreatywność oraz umożliwia sprawne zarządzanie czasem (...).

(...) Podczas edukacji online potrafię lepiej zarządzać moim czasem i nauką. Natomiast brakuje jednak trochę kontaktu z ludźmi na żywo (...).

(...) Dzięki tej formie łatwiej jest mi zarządzać moim czasem ze względu na brak konieczności dojeżdżania na uczelnię.

(...) Znalazłam czas na własne pasje, sama mogę organizować sobie czas pracy, dzięki czemu wiele go oszczędzam. 
W trakcie eksploracji empirycznych podjęto próbę ustalenia, czy ocena studentów dotycząca rozwoju ich kompetencji społecznych podczas nauki online jest różnicowana przez płeć. W celu sprawdzenia, czy istnieją różnice istotne statystycznie w ocenie rozwoju poszczególnych kompetencji społecznych dokonanej przez kobiety i mężczyzn, wykonano test $U$ Manna-Whitneya.

Tabela 5. Analiza różnic między kobietami i mężczyznami w ocenie poszczególnych kompetencji społecznych

\begin{tabular}{lcccccc}
\hline \multirow{2}{*}{$\begin{array}{l}\text { Kompetencje } \\
\text { społeczne }\end{array}$} & \multicolumn{2}{c}{$\begin{array}{c}\text { Kobiety } \\
\text { (N=276) }\end{array}$} & \multicolumn{2}{c}{$\begin{array}{c}\text { Mężczyźni } \\
\text { (N=74) }\end{array}$} & Z & p \\
\cline { 2 - 5 } & Średnia & $\begin{array}{l}\text { Odch. } \\
\text { Stand. }\end{array}$ & Średnia & $\begin{array}{c}\text { Odch. } \\
\text { Stand. }\end{array}$ & & \\
\hline WYR & 3,75 & 0,99 & 3,31 & 0,98 & 3,5283 & $0,000^{* *}$ \\
\hline POD & 2,93 & 1,21 & 2,50 & 1,25 & 2,7170 & $0,007^{*}$ \\
\hline EMP & 3,51 & 1,05 & 2,97 & 1,09 & 3,7104 & $0,000^{* *}$ \\
\hline KRE & 3,31 & 1,19 & 2,78 & 1,14 & 3,3370 & $0,001^{* *}$ \\
\hline INN & 3,57 & 1,06 & 3,32 & 1,02 & 1,8337 & 0,067 \\
\hline PRG & 3,27 & 1,28 & 2,93 & 1,23 & 2,1256 & $0,034^{* *}$ \\
\hline ORG & 3,75 & 1,23 & 3,08 & 1,30 & 3,9780 & $0,000^{* *}$ \\
\hline ZARZ & 3,87 & 1,18 & 3,11 & 1,28 & 4,6362 & $0,000^{* *}$ \\
\hline SYS & 3,00 & 1,33 & 2,41 & 1,13 & 3,4091 & $0,001^{* *}$ \\
\hline
\end{tabular}

${ }^{* *} \mathrm{p}<0,001 ;{ }^{*} \mathrm{p}<0,05$

Źródło: badania własne.

Różnice między kobietami a mężczyznami w ewaluacji rozwoju poszczególnych kompetencji społecznych są istotne statystycznie w odniesieniu do ośmiu z dziewięciu kompetencji ( $<<0,05)$. Różnica w zakresie innowacyjnego podejścia do rozwiązywania problemów jest na poziomie trendu ( $p=0,067)$. Kobiety wyżej oceniły każdą z branych pod uwagę w badaniu kompetencji społecznych. Analizując wartości średnie, można stwierdzić, iż największe różnice między kobietami a mężczyznami odnotowano w zakresie oceny rozwoju takich kompetencji jak: zarządzanie sobą w czasie ( $<<0,001)$, organizacja i planowanie własnej pracy $(\mathrm{p}<0,001)$ oraz systematyczność w uczeniu się $(\mathrm{p}<0,001)$.

Postanowiono sprawdzić również, czy ocena studentów dotycząca rozwoju ich kompetencji społecznych podczas nauki online jest różnicowana przez tryb studiów. Okazuje się, że tak, na co wskazuje analiza wyników testu U Manna-Whitneya. 
Tabela 6. Analiza różnic między studentami studiów dziennych i zaocznych w ocenie poszczególnych kompetencji społecznych

\begin{tabular}{lcccccc}
\hline \multirow{2}{*}{$\begin{array}{c}\text { Kompetencje } \\
\text { społeczne }\end{array}$} & \multicolumn{2}{c}{$\begin{array}{c}\text { Studenci dzienni } \\
\mathbf{( N = 2 8 7 )}\end{array}$} & \multicolumn{2}{c}{$\begin{array}{c}\text { Studenci zaoczni } \\
\mathbf{( N = 7 3 )}\end{array}$} & Z & p \\
\cline { 2 - 5 } & Średnia & $\begin{array}{c}\text { Odch. } \\
\text { Stand. }\end{array}$ & Średnia & $\begin{array}{c}\text { Odch. } \\
\text { Stand. }\end{array}$ & & \\
\hline WYR & 3,61 & 1,00 & 3,87 & 0,98 & $-1,9964$ & $0,046^{*}$ \\
\hline POD & 2,74 & 1,21 & 3,29 & 1,24 & $-3,0999$ & $0,002^{*}$ \\
\hline EMP & 3,34 & 1,07 & 3,65 & 1,12 & $-2,0609$ & $0,039^{*}$ \\
\hline KRE & 3,15 & 1,19 & 3,43 & 1,21 & $-1,6895$ & 0,091 \\
\hline INN & 3,48 & 1,03 & 3,71 & 1,17 & $-1,8832$ & 0,060 \\
\hline PRG & 3,17 & 1,26 & 3,33 & 1,32 & $-0,9413$ & 0,347 \\
\hline ORG & 3,54 & 1,31 & 3,90 & 1,07 & $-1,8255$ & 0,068 \\
\hline ZARZ & 3,64 & 1,28 & 4,03 & 1,02 & $-2,0233$ & $0,043^{*}$ \\
\hline SYS & 2,76 & 1,31 & 3,41 & 1,21 & $-3,6078$ & $0,000^{* *}$ \\
\hline
\end{tabular}

${ }^{* *} \mathrm{p}<0,001 ; * \mathrm{p}<0,05$

Źródło: badania własne.

Różnice między studentami studiującymi w trybie dziennym a zaocznym są istotne statystycznie w odniesieniu do pięciu kompetencji społecznych. Studenci studiów zaocznych wyżej niż studenci studiów dziennych ocenili rozwój umiejętności wyrażania własnego zdania $(\mathrm{p}<0,05)$, podtrzymywania relacji $(\mathrm{p}<0,002)$, empatii $(\mathrm{p}<0,04)$, zarządzania sobą w czasie $(\mathrm{p}<0,04)$ i systematyczności w uczeniu się $(\mathrm{p}<0,001)$. Analizując wartości średnie, ustalono, iż największe rozbieżności między studentami dziennymi a zaocznymi pojawiły się w ocenie systematyczności w uczeniu się ( $M=2,76 ; M=3,41)$, w rozwoju umiejętności podtrzymywania relacji $(M=2,74 ; M=3,29)$, zarządzania sobą w czasie $(M=3,64 ; M=4,03)$ oraz planowania i organizacji pracy własnej $(\mathrm{M}=3,54 ; \mathrm{M}=3,90)$.

Ostatni problem, który starano się rozwiązać w toku dociekań badawczych, zawierał się w pytaniu, czy ocena studentów dotycząca rozwoju ich kompetencji społecznych jest różnicowana przez okres studiowania online. W celu sprawdzenia, czy istnieją różnice istotne statystycznie w ocenie rozwoju poszczególnych kompetencji społecznych dokonanej przez osoby studiujące online krótko (jeden semestr) a długo (co najmniej dwa semestry), wykonano test $U$ Manna-Whitneya (tabela 7).

Analiza rezultatów zawartych w tabeli 7 wskazuje na to, że istotne różnice między studentami studiującymi online jeden semestr, ponieważ w roku akademickim 2020/2021 dopiero rozpoczęli studia, a tymi, którzy zaliczyli już co najmniej dwa 
Tabela 7. Analiza różnic w ocenie poszczególnych kompetencji społecznych między studentami studiującymi online krótko i studentami studiującymi długo.

\begin{tabular}{|c|c|c|c|c|c|c|}
\hline \multirow{2}{*}{$\begin{array}{l}\text { Kompeten- } \\
\text { cje społeczne }\end{array}$} & \multicolumn{2}{|c|}{$\begin{array}{l}\text { Studiujący krótko } \\
(\mathrm{N}=251)\end{array}$} & \multicolumn{2}{|c|}{$\begin{array}{c}\text { Studiujący długo } \\
(\mathrm{N}=99)\end{array}$} & \multirow{2}{*}{$\mathbf{Z}$} & \multirow{2}{*}{$\mathbf{p}$} \\
\hline & Średnia & $\begin{array}{l}\text { Odch. } \\
\text { Stand. }\end{array}$ & Średnia & $\begin{array}{l}\text { Odch. } \\
\text { Stand. }\end{array}$ & & \\
\hline WYR & 3,61 & 0,99 & 3,79 & 1,01 & $-1,8511$ & 0,064 \\
\hline POD & 2,82 & 1,25 & 2,89 & 1,19 & $-0,5419$ & 0,588 \\
\hline EMP & 3,44 & 1,09 & 3,28 & 1,06 & 1,1661 & 0,244 \\
\hline KRE & 3,23 & 1,17 & 3,12 & 1,26 & 0,5812 & 0,561 \\
\hline INN & 3,62 & 1,06 & 3,26 & 1,02 & 3,0803 & $0,002 * *$ \\
\hline PRG & 3,20 & 1,28 & 3,19 & 1,25 & 0,0932 & 0,926 \\
\hline ORG & 3,68 & 1,25 & 3,41 & 1,32 & 1,7149 & 0,086 \\
\hline ZARZ & 3,78 & 1,21 & 3,52 & 1,30 & 1,7040 & 0,088 \\
\hline SYS & 2,98 & 1,32 & 2,62 & 1,27 & 2,3419 & 0,019* \\
\hline
\end{tabular}

${ }^{* *} \mathrm{p}<0,01 ;{ }^{*} \mathrm{p}<0,05$

Źródło: badania własne.

semestry i mieli doświadczenie studiowania stacjonarnie, są istotne statystycznie w zakresie rozwoju umiejętności innowacyjnego rozwiązywania problemów $(p<0,002)$ oraz systematyczności w uczeniu się $(p<0,02)$. Analiza wartości średnich wskazuje na to, że studenci, którzy rozpoczynając studia, od razu weszli w edukację online, istotnie wyżej oceniają rozwój wymienionych kompetencji. Również wyżej oceniają rozwój umiejętności zarządzania sobą w czasie oraz organizacji i planowania pracy własnej, choć różnice są jedynie na poziomie trendu $(\mathrm{p}<0,09)$.

\section{DYSKUSJA WYNIKÓW}

W toku dociekań empirycznych poszukiwano odpowiedzi na pytanie, jak studenci oceniają rozwój swoich kompetencji społecznych w związku z nauką online, która stała się koniecznością ze względu na pandemię COVID-19. Okazało się, że studenci najwyżej ocenili umiejętność wyrażania własnego zdania, zarządzania sobą w czasie oraz organizacji i planowania pracy własnej. Podejmując próbę interpretacji tych wyników, zwrócono uwagę na opinie studentów dotyczące edukacji online, w których wskazują oni zarówno na plusy, jak i minusy tej formy nauki. Na przykład: 
[Edukacja online] (...) z jednej strony ułatwia pogodzenie w czasie wielu powinności, obowiązków i czuję się bardziej ośmielona do wypowiadania własnego zdania, przemyśleń (nawet gdy gotuję obiad, lub piorę), a z drugiej nauka online uniemożliwia pracę w grupach w różnych formach, czasem daje możliwość niekoncentrowania się w 100\% na zajęciach, co negatywnie wpływa na nabywanie kompetencji zawodowych, naukowych. Edukacja online jest mniej stresująca niż stacjonarna.

Studenci wielokrotnie podkreślali także, że dzięki temu, że nie muszą dojeżdżać na uczelnię, mają więcej czasu na realizację swoich zainteresowań i pasji.

[Edukacja online] jest wspaniała, ogromną korzyścią jest brak dojazdów do siedziby, a więc więcej czasu dla rodziny i hobby.

Nauka online pozwala mi zaoszczędzić czas na dojazdy do uczelni, który mogę poświęcić nauce. Dzięki nauczaniu online mogę także zająć się obowiązkami domowymi, których nie mogę zaniedbać na cały dzień.

Z drugiej strony, studenci nisko ocenili możliwość podtrzymywania relacji. W swoich wypowiedziach wskazywali na potrzebę bezpośredniego kontaktu z rówieśnikami i wykładowcami. Bardzo nisko oceniona została systematyczność w uczeniu się, co niekoniecznie musi wiązać się tylko z nauką online, a ze specyfiką studiowanych kierunków, które często wymagają największej aktywności od studentów dopiero podczas sesji zaliczeniowej i egzaminacyjnej.

Badania pokazały, że kobiety wyżej oceniły rozwój swoich kompetencji społecznych w trakcie edukacji online. Być może jest tak dlatego, że ciąży na nich społecznie i kulturowo zdeterminowane oczekiwanie, że będą lepsze w tej dziedzinie od mężczyzn, i może dlatego też mężczyźni mniej chętnie podkreślają znaczenie tych kompetencji w swoim życiu i nieco niżej się oceniają w tym obszarze. Pod pewnym względem podobne rezultaty w swoim projekcie badawczym uzyskała A. Rakowska (2018), kobiety częściej niż mężczyźni jako swoje mocne strony wskazywały: organizację czasu pracy własnej, komunikację interpersonalną, współpracę z przedstawicielami w różnym wieku, mobilizację do długookresowej pracy, umiejętność wykonywania dodatkowych zadań oraz znajomość języków obcych. Natomiast mężczyźni częściej niż kobiety wybierali jako swoje silne strony następujące umiejętności: radzenie sobie ze stresem, zarządzanie karierą, zarządzanie konfliktem, współpracę z przedstawicielami innej płci, przywództwo i władzę (Rakowska, 2018, s. 137). 
W oparciu o zaprezentowane w tym artykule badania stwierdzono, że tryb studiów ma znaczenie dla oceny rozwoju kompetencji społecznych. Okazuje się, że studenci studiów zaocznych istotnie wyżej ocenili możliwość kształtowania swoich kompetencji w trakcie nauki online. Prawdopodobnie to właśnie dla studentów studiów niestacjonarnych oszczędność czasu związana z brakiem konieczności dojeżdżania na uczelnię ma szczególne znaczenie. Często są to osoby godzące studia z pracą zawodową oraz życiem rodzinnym. Ze względu na to, że realizują się w różnych rolach, w których kształtują nieustannie ważne życiowo kompetencje, to edukacja online nie stanowi dla nich przeszkody, a jedynie dodatkowe źródło szlifowania ich.

Analiza rezultatów badań wskazuje także na to, że studenci, którzy rozpoczęli edukację uniwersytecką od razu w formie online, istotnie wyżej oceniają rozwój umiejętności innowacyjnego rozwiązywania problemów oraz systematyczności w uczeniu się niż studenci starsi, którzy mieli doświadczenie studiowania stacjonarnego. Świadczyć to może o adaptacji studentów pierwszego roku do tego rodzaju nauki, z którym zetknęli się także na etapie przygotowań do matury. Studenci starszych lat, mający możliwość studiowania w sposób tradycyjny, prawdopodobnie mają nieco inne przyzwyczajenia i oczekiwania związane ze studiowaniem, dlatego dopiero uczą się lepszego zarządzania sobą w czasie i innowacyjnego podejścia do rozwiązywania problemów w tej nowej dla nich rzeczywistości, kontrastującej znacząco z wcześniejszymi doświadczeniami edukacji na poziomie wyższym.

Studenci po zakończeniu cyklu kształcenia w ramach danego przedmiotu powinni nabyć określoną wiedzę, umiejętności i kompetencje społeczne. Tymczasem pandemia i szereg ograniczeń z nią związanych utrudniły w sposób znaczący kontakty interpersonalne, możliwość nawiązywania relacji czy integrację z rówieśnikami. W związku z tym monitorowanie, w jakim stopniu możliwe jest rozwijanie u studentów kompetencji społecznych, wydaje się zadaniem ważnym i aktualnym.

Omawiane badania, w odniesieniu do badanej próby, nie pozwalają na jednoznaczne stwierdzenie o zabarwieniu pejoratywnym, iż edukacja online uniemożliwia rozwój kompetencji społecznych. Daje ona na pewno szansę na lepsze zarządzanie sobą w czasie i organizowanie pracy własnej, utrudnia jednak znacząco podtrzymywanie bliskich relacji. Żeby nie dopuścić do utraty tej możliwości, i jednocześnie nie stracić korzyści wynikających z edukacji online, warto w przyszłości realizować nauczanie hybrydowe. Wartym zbadania byłyby także osobowościowe i ekonomiczne uwarunkowania preferencji dotyczących formy edukacji (stacjonarna, hybrydowa, online), a także kwestie dotyczące odpowiedzialności i uczciwości studentów podczas zajęć, zaliczeń i egzaminów. 


\section{Bibliografia}

Agnieszka Franczyk, Anna Rajchel

Argyle, M. (2001). Psychologia stosunków międzyludzkich. Warszawa: Wydawnictwo Naukowe PWN.

Armstrong, M. (2000). Zarządzanie zasobami ludzkimi. Kraków: Oficyna Ekonomiczna, Dom Wydawniczy ABC.

Doroszewski, W. (red.). Słownik języka polskiego. Pobrane z: https://sjp.pwn.pl/szukaj/ kompetencje.html.

Dudzińska-Głaz, J. (2012). Zarządzanie kompetencjami pracowników jako jeden z elementów strategicznego zarządzania zasobami ludzkimi. W: W. Harasim (red.), Zarzq̨dzanie kapitałem intelektualnym w organizacji inteligentnej. Warszawa: Wyższa Szkoła Promocji. Pobrane z: http://wsp.pl/index.php/pl,9,87,1057,2,12012_zarzadzanie_kapitalem_intelektualnym_w_oerganizacji_inteligentnej_.

Fastnacht, D. (2006). Miękkie kompetencje w zarządzaniu. Zeszyty Naukowe Wyższej Szkoły Zarzq̨dzania Ochronq Pracy w Katowicach, 1 (2), s. 110. Pobrane z: http:// yadda.icm.edu.pl/baztech/element/bwmeta1.element.baztech-article-BUS6-0031-0043.

Henne, K. (2003). Kompetencja społeczna i inteligencja emocjonalna a zaangażowanie w Internet. Psychologia Jakości Życia, t. 2, nr 1, s. 113. Pobrane z: https://depot.ceon. pl/bitstream/handle/123456789/1966/Kompetencja\%20spo\%c5\%82eczna\%20i\%20 inteligencja\%20emocjonalna\%20a\%20zaanga\%c5\%bcowanie\%20w\%20Internet. pdf?sequence=1\&isAllowed=y0.

Kocór, M. (2011). Kompetencje przyszłych i czynnych zawodowo nauczycieli. Edukacja. Internet. Dialog, marzec/kwiecień. Pobrane z: http://edukacjaidialog.pl/archiwum/2011,385/marzec-kwiecien,386/kompetencje,2334.html.

Kompetencje społeczne. Pobrane z: https://mlodziwdzialaniu.pzg.org.pl/wp-content/uploads/2019/07/Kompetencje-spo\%C5\%82eczne.pdf.

Kompetencje kulturowe w edukacji. Przewodnik dla nauczycieli. Kuratorium Oświaty w Katowicach, s. 17. Pobrane z: http://www.kuratorium.katowice.pl/wp-content/ uploads/2019/01/przewodnik-dla-nauczycieli.pdf.

Miłaszewicz, D. (2017). Kompetencje społeczne w świetle wyników badań kapitału społecznego studentów z Polski, Litwy i Słowacji, Studia i Prace WNEIZ US, 47/1, 2017. DOI: 10.18276/sip.2017.47/1-13, s. 151.

Okoń, W. (1981). Słownik pedagogiczny. Warszawa: Państwowe Wydawnictwo Naukowe. Pankowska, D. (2016). Kompetencje nauczycielskie - próba syntezy (projekt autorski). Lubelski Rocznik Pedagogiczny, t. XXXV, z. 3, 189. DOI: 10 .17951/lrp .2016 .35 .3 .187. Pobrane z: http://cejsh.icm.edu.pl/cejsh/element/bwmeta1.element.ojs-doi-10_17951_lrp_2016_35_3_187.

Pocztowski, A. (2008). Zarzqdzanie zasobami ludzkimi. Strategie - procesy -metody. Warszawa: Polskie Wydawnictwo Ekonomiczne.

Polska Rama Kwalifikacji. Poradnik użytkownika. (2018). Warszawa, s. 10. Pobrane z: https://kwalifikacje.edu.pl/polska-rama-kwalifikacji-poradnik-uzytkownika/.

Rakowska, A. (2018). Samoocena potencjału kompetencyjnego przez kobiety i mężczyzn na przykładzie pracowników innowacyjnych przedsiębiorstw. Zarzqdzanie i Finanse, 1, s. 133-141. 
Rogozińska-Pawełczyk, A. (2006). Kompetencje w organizacji. Acta Universitatis Lodziensis. Folia Oeconomica, 199, s. 101. Pobrane z: https://dspace.uni.lodz.pl/xmlui/bitstream/handle/11089/17674/foe199_Anna_Rogozi\%C5\%84ska_Pawelczyk_99_120. pdf?sequence $=1$ \&isAllowed $=\mathrm{y}$.

Siek-Piskozub, T. (2012). Międzykulturowa kompetencja komunikacyjna wyzwaniem dla glottodydaktyki. Lingwistyka Stosowana, 5, s. 96. Pobrane z: http://www.ls.uw.edu.pl/ documents/7276721/11201131/LS5_2012_art_SIEK-PISKOZUB.pdf.

Szymczak, M. (red.). (1982). Słownik języka polskiego. T. 2. Warszawa: Państwowe Wydawnictwo Naukowe.

Ustawa z dnia 22 grudnia 2015 r. o Zintegrowanym Systemie Kwalifikacji (Dz. U. 2016 poz. 64 z późn. zm).

Whiddett, S., Hollyforde, S. (2003). Modele kompetencyjne w zarządzaniu zasobami ludzkimi. Tłum. G. Sałuda. Kraków: Oficyna Ekonomiczna.

Wielki Słownik Języka Polskiego. Pobrane z: https://www.wsjp.pl/index.php?id_hasla$=6956 \&$ ind $=0 \&$ w_szukaj=kompetencje.

Włoch, R., Śledziewska, K. Kompetencje przyszłości. Jak je kształtować w elastycznym ekosystemie edukacyjnym. DELab UW, s. 11. Pobrane z: https://www.delab.uw.edu.pl/ wpcontent/uploads/2019/09/Kompetencje_przyszlosci_Raport_DELabUW.pdf.

Zalecenie Rady z dnia 22 maja 2018 r. w sprawie kompetencji kluczowych w procesie uczenia się przez całe życie. (Tekst mający znaczenie dla EOG) (2018/C 189/01), Dziennik Urzędowy Unii Europejskiej. Pobrane z: https://eur-lex.europa.eu/legal-content/PL/TXT/PDF/?uri=CELEX:32018H0604(01)\&from=en.

Załoga, W. (2013). Model kompetencji menedżera w nowoczesnej organizacji. Zeszyty Naukowe Uniwersytetu Przyrodniczo-Humanistycznego w Siedlcach, 97, Seria: Administracja i Zarządzanie, s. 457-458. Pobrane z: https://repozytorium.uph.edu.pl/ bitstream/handle/11331/730/Zaloga_Model_kompetencji_menedzera.pdf?sequence=1. 